\title{
Analisis Pesebaran Penularan Virus Corona Di Provinsi Jawa Tengah Menggunakan Metode K-Means Clustering
}

\author{
Darmansah* $^{* 1}$, Ni Wayan Wardani ${ }^{2}$ \\ ${ }^{1}$ Institut Teknologi Telkom Purwokerto; Jl. DI. Panjaitan No.128 Purwokerto, \\ Telp 0281-641629 \\ ${ }^{2}$ STMIK STIKOM Indonesia; Jl. Tukad Pakerisan No. 97 Panjer, Denpasar \\ e-mail: *11armansah@ittelkom-pwt.ac.id, ${ }^{2}$ niwayan.wardani@stiki-indonesia.ac.id
}

\begin{abstract}
Abstrak
Saat ini virus corona atau Covid-19 telah berkembang pesat dan telah dilaporkan hampir diseluruh dunia terpapar penuluran virus corona. Covid-19 telah merengut ribuan nyawa manusia di China hanya dalam waktu 3 bulan bahkan virus ini telah menyebar ke negara-negara lain seperti Italia, Iran, Korea Selatan, Inggris, Jepang, Amerika, Jerman, dan bahkan di Indonesia. Salah satu provinsi di Indonesia yang menjadi penularan virus corona adalah di provinsi jawa tengah (Prov. Jateng). Virus corona ini telah menyebar di berbagai kabupaten dan kota se-Jawah Tengah. Terdapat 35 kabupaten/kota di Jawa Tengah yang menjadi penularan virus corona. Untuk memudahkan pemerintah daerah Jawa Tengah dalam mengambil tindakan pencegahan penuluran virus corona maka perlunya peneliti untuk menentukan tingkat pesebaran penuluran virus corona yang di bagi menjadi tiga cluster. Cluster pertama yaitu $C O$ dengan kategori rendah, $C 1$ dengan kategori sedang dan $C 2$ dengan kategori pesebaran tinggi. Didalam analisis tingkat pesebaran penuluran virus corona ini peneliti menggunakan metode data mining dan algoritma K-Means Clustering untuk mengelompokan data pesebaran. Kemudian dalam pengolahan data peneliti menggunakan aplikasi Rapidminer Studio 7.6. Dari hasil penelitian ini didapatkan bahwa CO terdapat 18 kotal kabupaten, C1 terdapat 1 kotal kabupaten dan C2 terdapat 16 kotal kabupaten tingkat persebaran virus corona di provinsi Jawa Tengah.
\end{abstract}

Kata kunci-Analisis, Covid-19, Datamining, K-Means Clustering.

\begin{abstract}
Currently the corona virus or Covid-19 has developed rapidly and it has been reported that almost all over the world have been exposed to the transmission of the corona virus. Covid19 has claimed thousands of human lives in China in just 3 months. This virus has even spread to other countries such as Italy, Iran, South Korea, England, Japan, America, Germany, and even in Indonesia. One of the provinces in Indonesia that has contracted the corona virus is the province of Central Java (Prov. Central Java). This corona virus has spread in various districts and cities in Central Jawah. There are 35 districts / cities in Central Java that have contracted the corona virus. To make it easier for the Central Java regional government to take measures to prevent the spread of the corona virus, it is necessary for researchers to determine the level of spread of the corona virus which is divided into three clusters. The first cluster is $\mathrm{CO}$ with a low category, $C 1$ with a medium category and C2 with a high spread category. In the analysis
\end{abstract}


of the spread of the corona virus, the researchers used data mining methods and the K-Means Clustering algorithm to classify the distribution data. Then in data processing researchers use the Rapidminer Studio 7.6 application. From the results of the study, it was found that CO there were 18 cities / districts, C1 there were 1 city / regency and C2 there were 16 cities / districts where the spread of the corona virus was in Central Java province.

Keywords - Analysis, Covid-19, Datamining, K-Means Clustering

\section{PENDAHULUAN}

$P^{2}$ enyakit Corona virus (COVID-19) merupakan suatu penyakit yang baru ditemukan pada tahun akhir tahun 2019 lalu dan virus ini dapat menular. Orang-orang yang terinfeksi virus ini akan mendapati penyakit pernapasan dari kategori ringan hingga menengah dan dapat sembuh tanpa harus ada perawatan khusus. Penyakit ini dapat berkembang ke arah yang lebih serius untuk golongan orang tua dan orang-orang yang memiliki penyakit seperti kardiovaskular, diabetes, pernapasan kronis, dan kanker [1]. Saat ini COVID-19 atau virus corona telah berkembang pesat dan telah dilaporkan hampir diseluruh dunia. COVID-19 telah merengut ratusan bahkan ribuan nyawa manusia di China hanya dalam waktu kisaran 3 bulan bahkan virus ini telah menyebar ke negara-negara lain seperti Italia, Iran, Korea Selatan, Inggris, Jepang, Amerika, Jerman, dan bahkan di Indonesia sekalipun [2]. Sejak adanya pandemi COVID-19 di negara Indonesia, berbagai cara atau upaya telah dilakukan oleh pemerintah indonesia untuk menghindari terjadinya penularan covid-19 yang berkepanjangan di tanah air kita yaitu indonesia [3]. Salah satu provinsi di Indonesia yang menjadi penularan virus corona adalah di provinsi Jawa Tengah (Prov. Jateng). Virus cona ini telah menyebar di berbagai kabupaten dan kota se-Jawah Tengah. Terdapat 35 kabupaten/ kota di Jawa Tengah yang menjadi penularan virus corona. Adapun kabupaten kota yang menjadi pesebaran/penularan virus corona anatara lain yaitu Kota Semarang, Kudus, Jepara, Demak, Kendal, Semarang, Boyolali, Kebumen, Sukoharjo, Wonosobo, Magelang, Rembang, Surakarta, Karanganyar, Purworejo, Sragen, Blora, Temanggung, Grobogan, Banyumas, Klaten, Batang, Pati, Pemalang, Tegal, Banjarnegara, Pekalongan, Cilacap, Brebes, Pekalongan, Magelang, Salatiga, Purbalingga, Wonogiri dan Tegal. Hal ini tentu menyulitkan pemerintah untuk mengelompokan tingkat pesebaran atau penularan virus corona di Jawa Tengah. Pada penelitian ini, peneliti mengelompokan pesebaran penularan virus corona se-Jawa Tengah dengan mengelompokan tingkat pesebaran penuluran virus corona ke dalam tiga tingkatan berdasarkan kabupaten/ kota. Tingkatan pertama yaitu rendah (C0), Tingkat kedua yaitu Sedang (C1) dan Tinggi (C2). Dimana hasil penelitian ini bisa digunakan oleh pemerintah Jawa Tengah untuk mengabil kebijakan berdasarkan tingkat pesebarkan penularan virus corona berdasarkan kabupaten/ kota yang ada. Dalam pengelompokan tingkat pesebaran penuluran virus corona se Jawa Tengah ini, peneliti menggunakan metode Data Mining dan algoritma K-Means Clustering. Data mining merupakan suatu metode pengolahan data untuk menemukan pola yang tersembunyi dari data tersebut. Hasil dari pengolahan data dengan metode datamining ini dapat digunakan untuk mengambil keputusan di masa depan. Data mining ini juga dikenal dengan istilah pattern recognition [4]. Sedang K-Means merupakan suatu algoritma yang digunakan dalam pengelompokkan secara pertisi yang memisahkan data ke dalam kelompok yang berbeda berda. Algoritma ini mampu meminimalkan jarak antara data ke cluster nya. Pada dasarnya penggunaan algoritma ini dalam proses clustering tergantung pada data yang didapatkan dan konklusi yang ingin dicapaidi akhir proses [5]. Adapun penelitian sebelumnya yang menggunakan algoritma K-Means Clustering yaitu Penerapan Clustering Pada Penduduk Yang

Darmansah, et.,al (Analisis Pesebaran Penularan Virus Corona Di Provinsi Jawa Tengah Menggunakan Metode K-Means Clustering) 
Mempunyai Keluhan Kesehatan Dengan Datamining K-Means [6]. Analisa Penyebab Kerusakan Tanaman Cabai Menggunakan Metode K-Means [7]. Analisis Klasifikasi Tinggkat Kesehatan Lembaga Perkreditan Desa (Lpd) Menggunakan Metode K-Means Clustering [8]. Pengelompokan Dan Pemetaan Derajat Kesehatan Kota Bengkulu Dengan Metode K-Means Clustering [9]. Penerapan data mining untuk pengelompokan datarekam medis pasien berdasarkan jenis penyakitdengan algoritma clustering [10].

\section{LANDASAN TEORI}

\subsection{Knowledge Discovery in Database (KDD)}

Knowledge Discovery in Database (KDD) merupakan sebuah proses untuk menemukan pengetahuan yang berguna dalam sebuah basis data. Seluruh proses dari KDD biasanya terdiri dari beberapa tahapan -tahapan, yaitu yang pertama memahami bidang aplikasi, kedua membuat data target yang ditetapkan dari data mentah yang tersimpan dalam database, dan yang ketiga pembersihan data dan preprocessing data [7].

\subsection{Data Mining}

Pendekatan Data Mining menjadi sangat penting dalam mengambil sebuah keputusan berdasarkan analisis dari data klinis yang besar [7]. Data Mining adalah suatu metode pengolahan data untuk menemukan pola yang tersembunyi dari data tersebut [10]. Pendapat lain juga mengatakan bahwa Data mining adalah proses yang menggunakan teknik statistik, matematika, kecerdasan buatan, dan machine learning untuk mengekstraksi dan menidentifikasi informasi yang bermanfaat dan pengetahuan yang terkait dari berbagai database yang besar [11].

\subsection{Clustering}

Clustering merupakan proses pengelompokan objek berdasarkan informasi yang didapat dari data yang menjelaskan hubungan antar objek dengan prinsip untuk memaksimalkan kesamaan antar anggota satu kelas dan meminimumkan kesamaan antar kelas/ cluster [7]. Menurut pendapat lainnya mengatakan bahwa Clustering merupakan suatu alat bantu pada data mining yang bertujuan mengelompokkan objek-objek kedalam cluster-cluster atau kelompok [12].

\subsection{Algoritma K-Menas}

Algoritma K-Means merupakan sebuah metode yang berusaha mengelompokan data yang ada ke dalam beberapa kelompok, dimana data yang ada dalam satu kelompok mempunyai karakteryang sama satu sama lainnya dan mempunyai karakter yang berbeda dengan data yang ada dalam kelompok lain [7]. Menurut pendapatlainnya mengatakan bahwa K-Means merupakan salah satu metode data clusteringnon hirarki yang berusaha mempartisi data yang ada ke dalam bentuk satu atau lebih cluster atau kelompok sehingga data yang memiliki karakteristik yang sama dikelompokkan ke dalam satu cluster yang sama dan data yang mempunyai karakteristik yang berbeda dikelompokkan ke dalam kelompok yang lainnya [13]. AlgoritmeK-Means merupakan algoritme klasterisasi yang mengelompokkan data berdasarkan titik pusat klaster (centroid) terdekat dengan data. Tujuan dari K-Means adalah pengelompokkan data dengan memaksimalkan kemiripan data dalam satu klaster [14]. 


\section{METODE PENELITIAN}

Metodologi penelitian menjelaskan tentang tahapan penelitian secara sistematis sehingga dapat digunakan sebagai pedoman yang jelas dalam menyelesaikan dan membuat analasis dari hasil penelitian yang dilakukan. Adapun metode penelitian dapat dilihat pada gambar 1 dibawah ini:

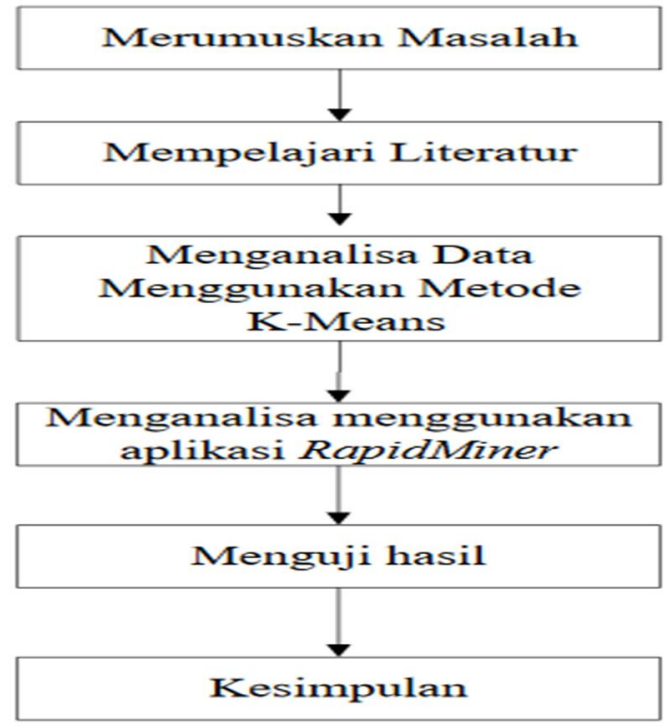

Gambar 1. Metode Penelitian

Pada kerangka kerja yang digambarkan adalah langkah-langkah atau cara sistematik atau metode yang dilakukan pada penelitian ini, agar langkah-langkah yang diambil peneliti dalam penelitian dapat lebih mudah dipahami. Berikut ini dijelaskan secara lebih detail mengenai metodologi pemecahan masalah dari tahapan kerangka kerja diatas sebagai berikut:

\subsection{Merumuskan Masalah}

Melakukan penetapan atau menentuan masalah yang akan menjadi penelitian. Dengan menentukan permasalahan yang ditemukan pada obyek yang diteliti guna mencari alternatif solusi yang bersangkutan dengan penelitian. Perumusan masalah dilakukan untuk memperoleh gambaran yang lengkap tentang lingkup masalah dan langkah yang tepat dalam pemecahannya serta membuat penelitian ini terarah dan tidak mengambang yaitu untuk mengetahui tingkat pesebaran virus corona di Jawa Tengah.

\subsection{Mepelajari Studi Literatur}

Tahapan ini merupakan pengumpulan dan mempelajari literatur yang berkaitan dengan tujuan serta mendapatkan referensi pendukung yang memadai baik berupa jurnal penelitian maupun buku-buku mengenai algoritma K-Means dan software Rapidminer serta literatur yang membahas tentang data pesebaran penuluran virus corona di Jawa Tengah untuk memperkuat pengetahuan dasar dan teori pendukung. Literatur dikumpulkan untuk memperkuat metode yang dipakai, dalam hal ini mengenai algoritma K-Means dan software Rapidminer.

\subsection{Menganalisa data dengan algoritma K-Means}

Pada tahap ini dilakukan analisa terhadap data pesebaran penuluran virus corona di Jawa Tengah yang di peroleh dari Dinas Kesehatan Provinsi Jawa Tengah yang telah di

Darmansah, et.,al (Analisis Pesebaran Penularan Virus Corona Di Provinsi Jawa Tengah Menggunakan Metode 
dapatkan dan dirumus perhitungan K-Means Clustering. Setelah dilakukan perhitungan maka akan didapat hasil dari data tersebut.

\subsection{Menganalisa Data Menggunakan Aplikasi RapidMiner}

Tahapan selanjutnya adalah menggunakan Rapidminer untuk mempercepat pengolahan data dengan algoritma $K$-Means Clustering, yaitu data pesebaran penuluran virus corona di Jawa Tengah yang di peroleh dari Dinas Kesehatan Provinsi Jawa Tengah.

\subsection{Menguji Hasil}

Proses ini merupakan proses analisa untuk menguji apakah hasil pengolahan dan penghitungan yang dilakukan itu benar, maka selanjutnya dilakukan implementasi dengan menggunakan perangkat lunak dalam sistem aplikasi sehingga dapat dilihat perbandingan dan kesesuaian dari hasil keputusan akhir yang didapatkan dari algoritma K-Means Clustering dengan menggunakan aplikasi Rapidminer.

\subsection{Menarik Kesimpulan}

Pada tahapan ini penulis dapat menarik kesimpulan dari penelitian ini, dimana kesimpulan ini dapat menjadi acuan bagi pihak yang ingin menggunakan hasil penelitian ini yaitu pemerintah Provinsi Jawa Tengah dalam mengetahui tingkat pesebaran penuluran virus corona se Jawa Tengah berdasarkan kabupaten dan kota. Pada tahap ini juga dapat saran yang diberikann terkait dengan penelitian yang dilakukan ini.

\section{HASIL DAN PEMBAHASAN}

Pada bagian ini peneliti menjelasakan sebuah gambaran proses analisa suatu masalah yang terjadi dan penerapan dari metode yang digunakan. Untuk membantu peneliti dalam menganalisis data dalam pencarian pengetahuan (knowledge), maka akan dilakukan transformasi data yang didapat pada hasil data dari Dinas Kesehatan Provinsi Jawa Tengah dalam bentuk file program pengolahan angka (spreadsheat). untuk melakukan pengolahan algoritma K-Means Clustering di olah dengan softwere Rapidminer Studio 7.6.

\subsection{Model Pemprosesan}

Di dalam penelitian ini peneliti melakukan analisis data pesebaran penuluran virus corona di Jawa Tengah dengan menggunakan algoritma K-Means Clustering. Berdasarkan litelatur yang ada maka penulis membuat langkah langkah atau metode pemrosesan $K$-Means Clustering Yaitu seperti gambar 2 dibawah ini: 


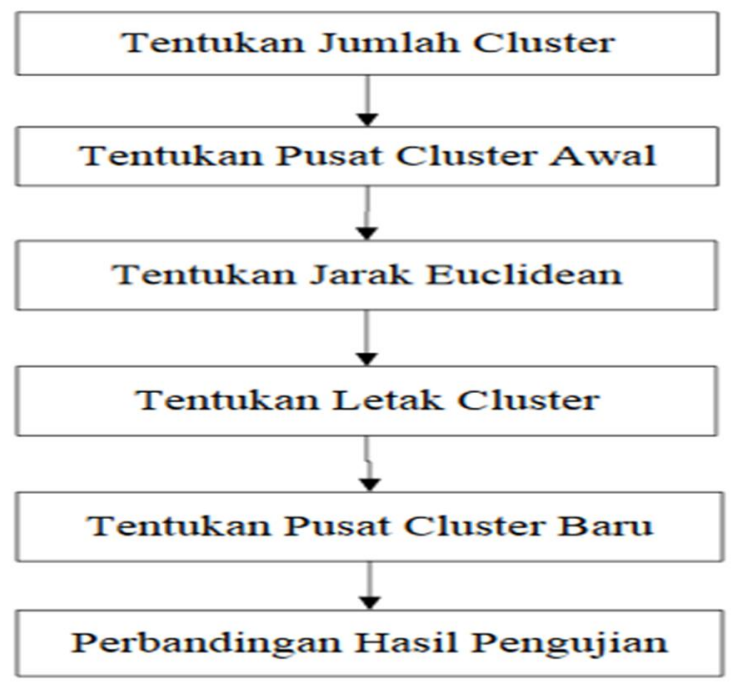

Gambar 2. Pemproses K-Menas Clustering

\subsection{Analisis Data}

Pada saat melakukan tahap penganalisaan data pesebaran penuluran virus corona di Jawa Tengah yang di peroleh dari Dinas Kesehatan Provinsi Jawa Tengah. Setelah data dikumpulkan kemudian data disusun dan dikelompokkan dalam bentuk tabel yang mudah dipahami dan dimengerti kedalam Softwere Microsoft Office Excel 2016.Tahap analisa yaitu proses pembahasan persoalan yang dilakukan sebelum membuat penyelesaian yang akan menjadi hasil utama penelitian.

\subsection{Data Set}

Dataset merupakan data yang digunakan dalam analisa tingkat pesebaran virus corona di jawa tengah, adapun data yang di gunakan adalah data yang di dapat pada Dinas Kesehatan Provinsi Jawa Tengah. Adapun bentuk dataset yang peneliti olah adalah seperti tabel 1 dibawah ini:

Tabel 1. Dataset

\begin{tabular}{lrrrrrr}
\hline $\begin{array}{l}\text { Kabupaten/ } \\
\text { Kota }\end{array}$ & Terkonfirmasi & Dirawat & Sembuh & Meninggal & Suspek & $\begin{array}{c}\text { Suspek } \\
\text { Discarded }\end{array}$ \\
\hline $\begin{array}{l}\text { Kota } \\
\text { Semarang }\end{array}$ & 5.119 & 311 & 4.214 & 594 & 376 & 2.401 \\
\hline Kudus & 1.743 & 273 & 1.262 & 208 & 135 & 707 \\
\hline Jepara & 1.675 & 236 & 1.306 & 133 & 101 & 348 \\
\hline Demak & 1.62 & 104 & 1.278 & 238 & 259 & 1.101 \\
\hline Kendal & 1.162 & 287 & 820 & 55 & 178 & 352 \\
\hline Semarang & 924 & 172 & 695 & 57 & 112 & 324 \\
\hline Boyolali & 885 & 127 & 725 & 33 & 37 & 349 \\
\hline Kebumen & 813 & 326 & 473 & 14 & 56 & 355 \\
\hline Sukoharjo & 719 & 130 & 548 & 41 & 121 & 498 \\
\hline
\end{tabular}

Darmansah, et.,al (Analisis Pesebaran Penularan Virus Corona Di Provinsi Jawa Tengah Menggunakan Metode 
ISSN 2407-4322

Vol. 8, No. 1, Maret 2021, Hal. 105-117

E- ISSN 2503- 2933111

\begin{tabular}{|c|c|c|c|c|c|c|}
\hline Wonosobo & 659 & 275 & 362 & 22 & 336 & 611 \\
\hline Magelang & 638 & 188 & 433 & 17 & 34 & 488 \\
\hline Rembang & 571 & 237 & 279 & 55 & 16 & 289 \\
\hline $\begin{array}{l}\text { Kota } \\
\text { Surakarta }\end{array}$ & 567 & 93 & 441 & 33 & 50 & 460 \\
\hline Karanganyar & 561 & 125 & 404 & 32 & 72 & 599 \\
\hline Purworejo & 557 & 71 & 476 & 10 & 129 & 97 \\
\hline Sragen & 554 & 81 & 444 & 29 & 28 & 363 \\
\hline Blora & 539 & 105 & 403 & 31 & 94 & 116 \\
\hline Temanggung & 525 & 116 & 385 & 24 & 110 & 212 \\
\hline Grobogan & 520 & 45 & 398 & 77 & 82 & 871 \\
\hline Banyumas & 494 & 107 & 373 & 14 & 36 & 596 \\
\hline Klaten & 423 & 166 & 237 & 20 & 102 & 399 \\
\hline Batang & 419 & 98 & 296 & 25 & 59 & 147 \\
\hline Pati & 414 & 79 & 254 & 81 & 190 & 425 \\
\hline Pemalang & 406 & 96 & 275 & 35 & 60 & 621 \\
\hline Tegal & 340 & 115 & 189 & 36 & 184 & 439 \\
\hline Banjarnegara & 254 & 51 & 190 & 13 & 30 & 165 \\
\hline Pekalongan & 254 & 62 & 169 & 23 & 16 & 72 \\
\hline Cilacap & 245 & 56 & 182 & 7 & 22 & 338 \\
\hline Brebes & 208 & 67 & 115 & 26 & 37 & 270 \\
\hline $\begin{array}{l}\text { Kota } \\
\text { Pekalongan }\end{array}$ & 206 & 63 & 124 & 19 & 4 & 32 \\
\hline $\begin{array}{l}\text { Kota } \\
\text { Magelang }\end{array}$ & 200 & 26 & 158 & 16 & 7 & 119 \\
\hline Kota Salatiga & 199 & 48 & 148 & 3 & 65 & 78 \\
\hline Purbalingga & 194 & 34 & 158 & 2 & 33 & 329 \\
\hline Wonogiri & 168 & 12 & 139 & 17 & 150 & 146 \\
\hline Kota Tegal & 121 & 39 & 71 & 11 & 11 & 101 \\
\hline
\end{tabular}

\subsection{Analisis Cluster}

Analisis cluster merupakan teknik analisis data yang bertujuan untuk mengelompokan individu/objek ke dalam beberapa kelompok yang memiliki sifat berbeda antar kelompok, sehingga individu/objek yang terletak dalam satu kelompok akan mempunyai sifat relatif sama. proses pengelompokan objek berdasarkan informasi yang diperoleh dari data yang menjelaskan hubungan antar objek dengan prinsip untuk memaksimalkan kesamaan antar anggota satu kelas dan meminimumkan kesamaan antar kelas/cluster.

\subsection{Menentukan Jumlah Cluster}

Dalam penelitian ini dilakukan pengelompokan berdasarkan data yang di dapat pada Dinas Kesehatan Provinsi Jawa Tengah. Adapun jumlah cluster atau kelompok di bagi menjadi tiga cluster yaitu:

1. Cluster kategori penyebaran penuluran rendah $\mathrm{C} 0$

2. Cluster kategori penyebaran penuluran sedang $\mathrm{C} 1$ 
3. Cluster kategori penyebaran penuluran tinggi $\mathrm{C} 2$

\subsection{Centroid Awal}

Centroit awal ini adalah data yang menjadi titik pusat cluster pertama dalam menentukan analisa tingkat pesebaran virus corona di jawa tengah. Adapun data yang menjadi nilai atau titik centroid awal seperti tabel 2 di bawah ini:

Tabel 2. Centoid Awal

\begin{tabular}{lrrrrrr}
\hline $\begin{array}{c}\text { Kabupaten } \\
\text { /Kota }\end{array}$ & $\begin{array}{r}\text { Terkon } \\
\text { firmasi }\end{array}$ & Dirawat & Sembuh & Meninggal & Suspek & $\begin{array}{c}\text { Suspek } \\
\text { Discarded }\end{array}$ \\
\hline Tegal & 340 & 115 & 189 & 36 & 184 & 439 \\
\hline Kendal & 1.162 & 287 & 820 & 55 & 178 & 352 \\
\hline Sragen & 554 & 81 & 444 & 29 & 28 & 363 \\
\hline
\end{tabular}

\subsection{Algotitma K-Means Clustering}

Untuk mengetahui analisa tingkat pesebaran penularan virus corona di jawa tengah peneliti menggunakan aplikasi rapidminer. Adapun langkah langkah yang peneliti lakukan adalah seperti berikut ini:

\subsubsection{Membuka Aplikasi Rapidminer}

Langkah yang pertama adalah membuka aplikasi Rapidminer, adapun bentuk tampilan adalah seperti berikut ini:

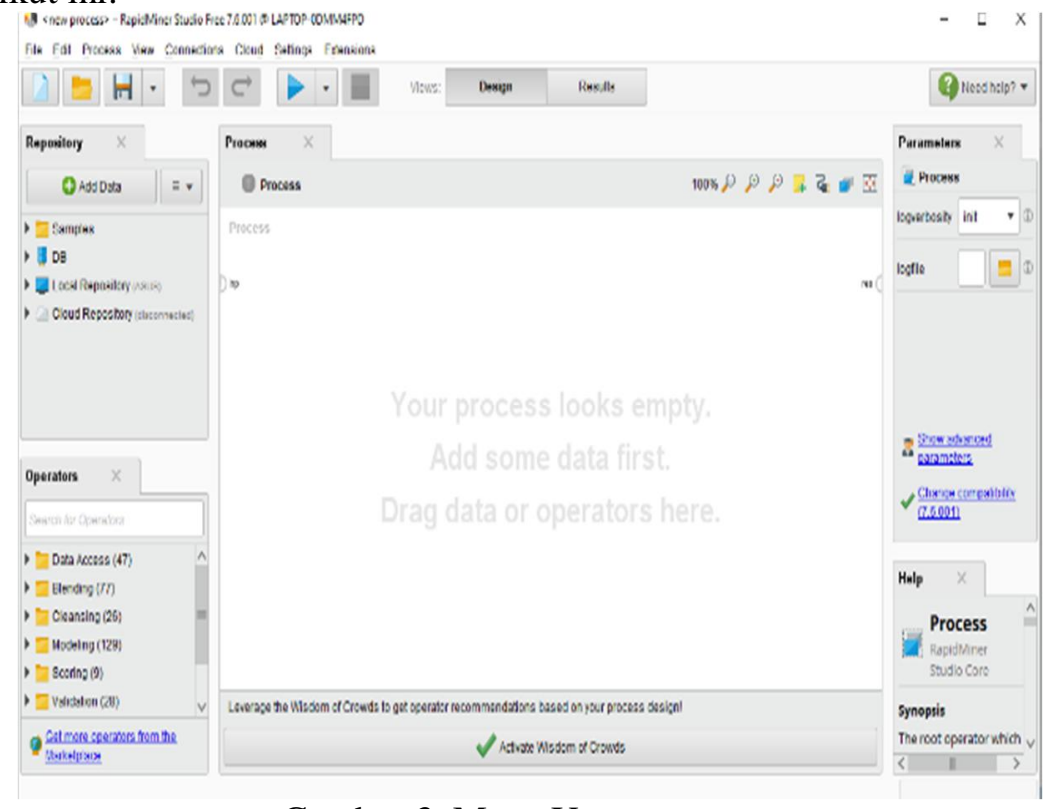

Gambar 3. Menu Utama

\subsubsection{Memasukan dataset ke dalam rapidminer}

Bagian ini yaitu memilih format data yang di masukan ke dalam aplikasi, adapun jenis format data yang penulismasukan kedalam aplikasi ini yaitu data dalam bentuk file Microsoft Office Exel. Adapun data yang dimasukan ke dalam aplikasi ini yaitu dataset yang telah di dapat sebelumnya.

Darmansah, et.,al (Analisis Pesebaran Penularan Virus Corona Di Provinsi Jawa Tengah Menggunakan Metode K-Means Clustering) 


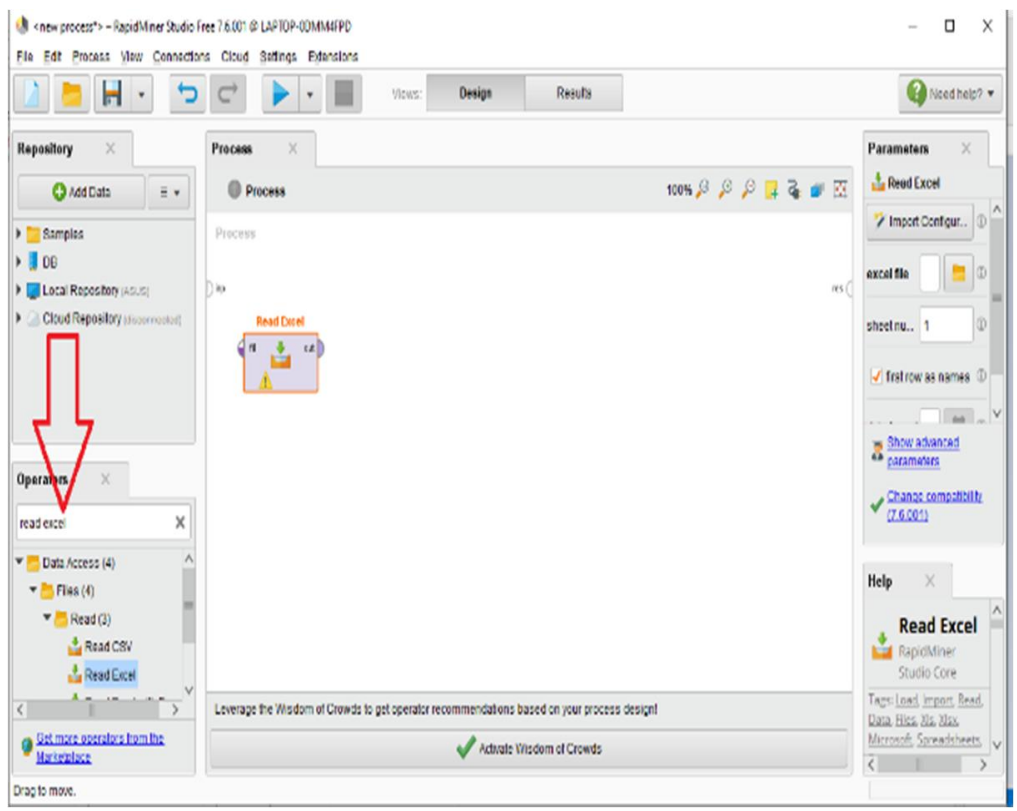

Gambar 4. Memasukan Dataset

\subsubsection{Proses K-Means Clustering}

Untuk melakukan proses clustering K-Means maka peneliti melakukan pengabung antara data yang masuk pada tool readexcel (dataset) dengan tool $K$-Means. Kemudian pada tool $K$-Means lakukan pemilihan jumlah cluster yang terdapat pada bagian kanan aplikasi di page kerja tool K-Means. isi jumlah cluster dan jumlah pengulangan yang akan dilakukan. Dalam kasus ini nilai $\mathrm{K}=3$ dan maksimal pengulangan 10 kali. Adapun gambarnya seperti berikut ini:

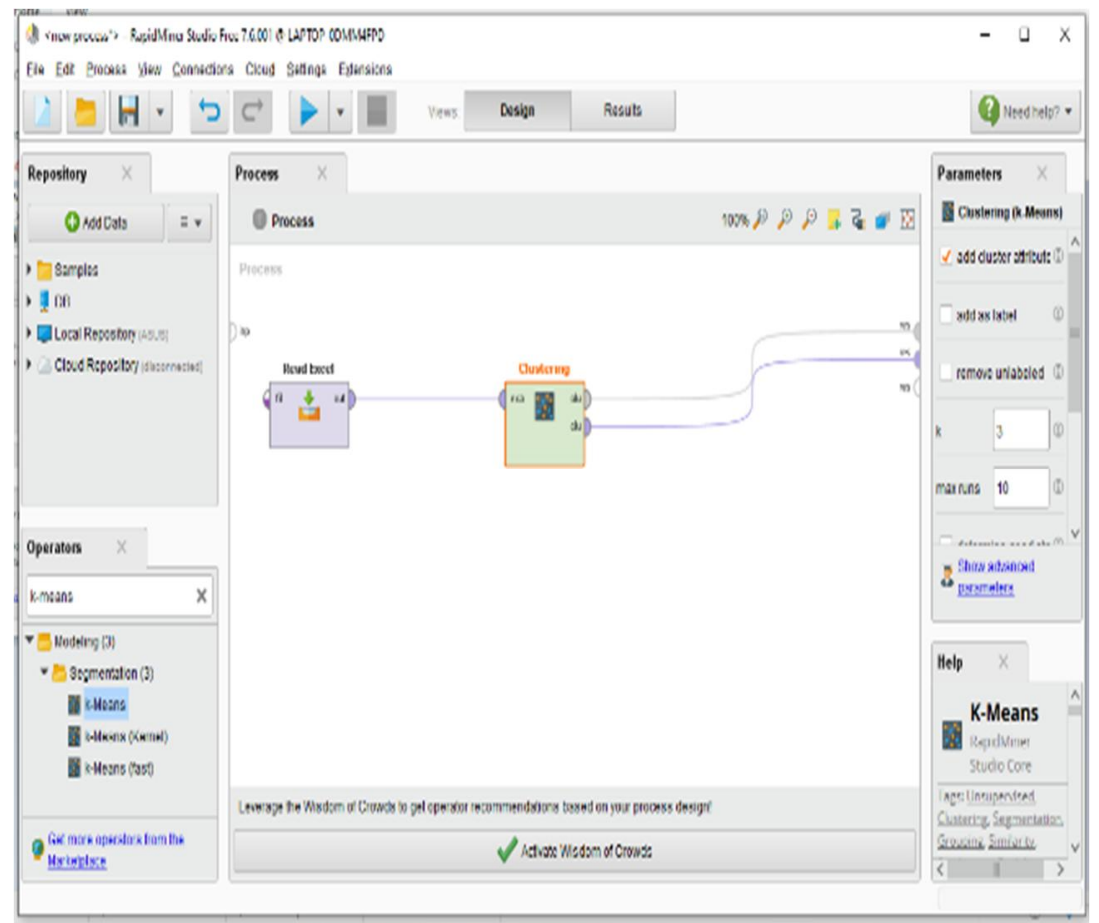

Gambar 5. Proses Clustering

Darmansah, et.,al (Analisis Pesebaran Penularan Virus Corona Di Provinsi Jawa Tengah Menggunakan Metode 


\subsubsection{Hasil Clustering}

Setelah di lakukan perhitungan dan proses $K$-Means Clustering, maka di dapatkan hasil cluster model seperti berikut ini:

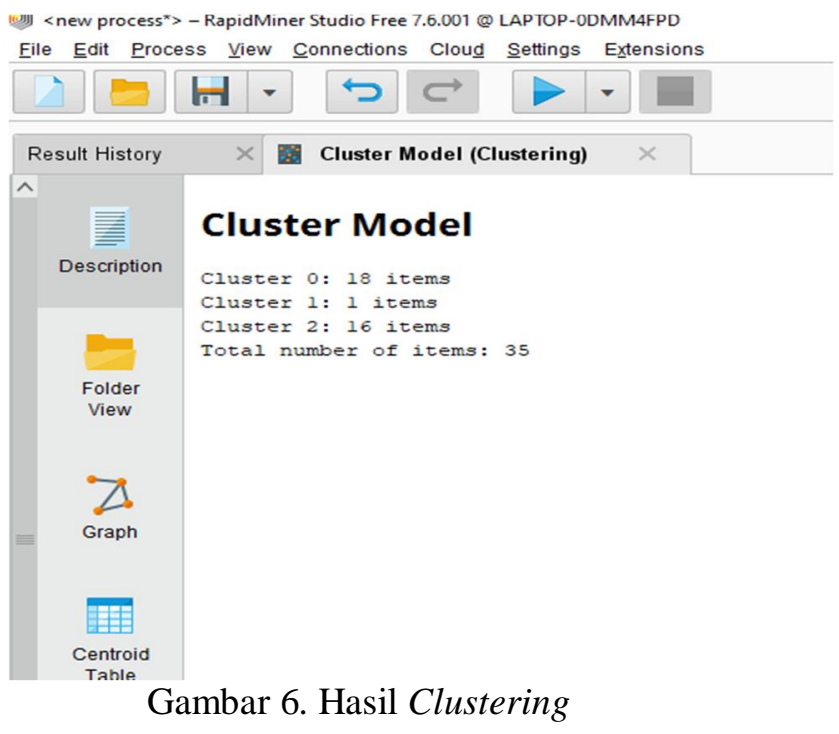

\subsubsection{Hasil Analasis}

Setelah melakukan perhitungan dasa dengan algoritma $K$-Means Clustering dengan aplikasi Rapidminer maka didapat hasil yaitu: terdapat tiga Cluster yaitu $\mathrm{C} 0, \mathrm{C} 1$ dan $\mathrm{C} 2$. Dimana C0 adalah tingkat pesebaran virus corona di kabupaten/ kota se-Jawa tengah dengan katergori rendah yang terdapat 18 kabupaten/ kota, C1 dengan kategori sedang terdapat 1 kabupaten/ kota dan C2 dengan kategori tinggi terdapat 16 kabupaten/kota. Adapun tabel pengelompokan antar cluster seperti tabel berikut ini:

Tabel 3. Hasil Analisis Kategori Rendah di Kabupaten/Kota se Jawa Tengah (C0)

\begin{tabular}{lll}
\hline No & Kabupaten/Kota & Cluster_0 \\
\hline \hline 1 & SEMARANG & Cluster_0 \\
\hline \hline 2 & BOYOLALI & Cluster_0 \\
\hline \hline 3 & KEBUMEN & Cluster_0 \\
\hline \hline 4 & SUKOHARJO & Cluster_0 \\
\hline \hline 5 & WONOSOBO & Cluster_0 \\
\hline \hline 6 & MAGELANG & Cluster_0 \\
\hline \hline 7 & REMBANG & Cluster_0 \\
\hline \hline 8 & KOTA & Cluster_0 \\
\hline \hline 9 & SURAKARTA & \\
\hline \hline 10 & PARANGANYAR & Cluster_0 \\
\hline \hline 11 & SRAGEN & Cluster_0 \\
\hline \hline 12 & BLORA & Cluster_0 \\
\hline \hline 13 & TEMANGGUNG & Cluster_0
\end{tabular}

Darmansah, et.,al (Analisis Pesebaran Penularan Virus Corona Di Provinsi Jawa Tengah Menggunakan Metode K-Means Clustering) 


\begin{tabular}{cll}
\hline 14 & GROBOGAN & Cluster_0 \\
\hline \hline 15 & BANYUMAS & Cluster_0 \\
\hline \hline 16 & KLATEN & Cluster_0 \\
\hline \hline 17 & PATI & Cluster_0 \\
\hline \hline 18 & PEMALANG & Cluster_0 \\
\hline
\end{tabular}

Tabel 4. Hasil Analisis Kategori Sedang di Kabupaten/Kota se Jawa Tengah (C1)

\begin{tabular}{lll}
\hline No Kabupaten/Kota & cluster_1 \\
\hline \hline 1 & KENDAL & cluster_1
\end{tabular}

Tabel 5. Hasil Analisis Kategori Tinggi di Kabupaten/Kota se Jawa Tengah (C2)

\begin{tabular}{|c|c|c|}
\hline No & Kabupaten Kota & Cluster_2 \\
\hline 1 & $\begin{array}{l}\text { KOTA } \\
\text { SEMARANG }\end{array}$ & cluster_2 \\
\hline 2 & KUDUS & cluster_2 \\
\hline 3 & JEPARA & cluster_2 \\
\hline 4 & DEMAK & cluster_2 \\
\hline 5 & BATANG & cluster_2 \\
\hline 6 & TEGAL & cluster_2 \\
\hline 7 & \multicolumn{2}{|c|}{ BANJARNEGARA cluster_2 } \\
\hline 8 & PEKALONGAN & cluster_2 \\
\hline 9 & CILACAP & cluster_2 \\
\hline 10 & BREBES & cluster_2 \\
\hline 11 & $\begin{array}{l}\text { KOTA } \\
\text { PEKALONGAN }\end{array}$ & cluster_2 \\
\hline 12 & $\begin{array}{l}\text { KOTA } \\
\text { MAGELANG }\end{array}$ & cluster_2 \\
\hline 13 & KOTA SALATIGA & cluster_2 \\
\hline 14 & PURBALINGGA & cluster_2 \\
\hline 15 & WONOGIRI & cluster_2 \\
\hline 16 & KOTA TEGAL & cluster 2 \\
\hline
\end{tabular}

\section{KESIMPULAN}

Berdasarkan hasil analisis dan pengujian yang peneliti lakukan dengan algoritma $K$ Means clustering terhadap data pesebaran penuluran virus corona di Jawa Tengah yang di peroleh dari Dinas Kesehatan Provinsi Jawa Tengah. maka dapat disimpulkan bahwa hasil penelitian ini adalah sebagai berikut ini: Analisa tingkat pesebaran virus corona di Jawa Tengah menggunakan algoritma $K$-Means Clustering dan menggunakan aplikasi Rapidminer dalam pengolahan data nya. Pada penelitian ini peneliti mendapat atau menentukan jumlah cluster terdiri dari tiga macam cluster yaitu $\mathrm{C} 0, \mathrm{C} 1$, dan $\mathrm{C} 2$. Dimana $\mathrm{C} 0$ adalah tingkat pesebaran virus 
corona di kabupaten/ kota se-Jawa tengah dengan katergori rendah, $\mathrm{C} 1$ dengan kategori sedang dan C2 dengan kategori tinggi.

Dataset yang digunakan berjumlah sebanyak 35 data hal ini berdasarkan jumlah kabupaten/ kota se-Jawa Tengah. kabupaten/ kota yang tergolong penyebaran penuluran virus corona terendah $(\mathrm{C} 0)$ di jawa tengah terdapat 18 kabupaten/ kota yaitu diantaranya adalah Semarang, Boyolali, Kebumen, Sukoharjo, Wonosobo, Magelang, Rembang, Surakarta, Karanganyar, Purworejo, Sragen, Blora, Temanggung, Grobogan, Banyumas, Klaten, Pati dan Pemalang.

Kemudian terdapat 1 kabupaten/ kota dengan penuluran virus corona sedang (C1) di jawa tengah yaitu kabupaten Kendal. Terdapat 16 kabupaten/ kota di Jawa Tengah yang kategori pesebaran penularan virus corona tertinggi (C2) di Jawa Tengah yaitu kota Semarang, Kudus, Jepara, Demak, Batang, Tegal, Banjarnegara, Pekalongan, Cilacap, Brebes, Pekalongan, Magelang, Salatiga, Purbalingga, Wonogiri dan Tegal.

\section{SARAN}

Dari kesimpulan diatas dapat diberikan saran-saran sebagai beriku:

1. Penulis sangat menyarankan agar dilakukan penelitian atau pengembangan lebih lanjut terhadap penelitian ini dengan metode metode lainnya seperti metode Fuzzy C-Means, Self Organizing Map, K-Modes dan lain-lain.

2. Hasil dari proses data mining ini dapat digunakan sebagai pertimbangan dalam mengambil keputusan lebih lanjut tentang kebijakan yang di lakukan dinas kesehatan provinsi Jawa Tengah dalam menangani tingkat pesebaran penularan virus corona di kabupaten/kota yang ada di Jawa Tengah, sehingga kualitas penanganan pencegahan virus corona semakin lebih baik.

\section{UCAPAN TERIMA KASIH}

Peneliti mengucapkan kepada semua pihak yang telah membantu demi terlaksananya penelitian ini yag tidak bisa peneliti sebutkan namanya satu perssatu.

\section{DAFTAR PUSTAKA}

[1] G. D. Rembulan, T. Wijaya, D. Palullungan, K. N. Alfina, And M. Qurthuby. 2020, Kebijakan Pemerintah Mengenai Coronavirus Disease (Covid-19) di Setiap Provinsi di Indonesia Berdasarkan Analisis Klaster, Jiems (Journal Ind. Eng. Manag. Syst., Vol. 13, No. 2, Doi: 10.30813/Jiems.V13i2.2280.

[2] Z. Zaharah And G. I. Kirilova. 2020, Impact of Corona Virus Outbreak Towards Teaching and Learning Activities In Indonesia, Salam J. Sos. Dan Budaya Syar-I, Vol. 7, No. 3, Doi: 10.15408/Sjsbs.V7i3.15104.

[3] K. D. R Sianipar, S. Wanti Siahaan, M. Siregar, And P. R. Fikrul Ilmi Zer, 2020, Penerapan Algoritma K-Means Dalam Menentukan Tingkat Kepuasan Pembelajaran Online Pada Masa Pandemi Covid-19, J. Teknol. Inf., Vol. 4, No. 1, Pp. 101-105.

Darmansah, et.,al (Analisis Pesebaran Penularan Virus Corona Di Provinsi Jawa Tengah Menggunakan Metode K-Means Clustering) 
[4] M. G. Sadewo, A. Eriza, A. P. Windarto, And D. Hartama. 2019, Algoritma K-Means Dalam Mengelompokkan Desa/Kelurahan Menurut Keberadaan Keluarga Pengguna Listrik dan Sumber Penerangan Jalan Utama Berdasarkan Provinsi, Semin. Nas. Teknol. Komput. Sains Sainteks 2019, Pp. 754-761.

[5] A. K. Wardhani, 2016, K-Means Algorithm Implementation for Clustering of Patients Disease In Kajen Clinic of Pekalongan, J. Transform., Vol. 14, No. 1, P. 30, Doi: 10.26623/Transformatika.V14i1.387.

[6] N. Rofiqo, A. P. Windarto, And D. Hartama. 2018, Penerapan Clustering pada Penduduk yang Mempunyai Keluhan Kesehatan Dengan Datamining K-Means, Komik (Konferensi Nas. Teknol. Inf. Dan Komputer), Vol. 2, No. 1, Pp. 216-223, Doi: 10.30865/Komik.V2i1.929.

[7] D. Darmansah. 2020, Analisa Penyebab Kerusakan Tanaman Cabai Menggunakan Metode K-Means, Jatisi (Jurnal Tek. Inform. dan Sist. Informasi), Vol. 7, No. 2, Pp. 126-134, Doi: 10.35957/Jatisi.V7i2.309.

[8] M. A. Raharja And I. W. Supriana. 2019, Analisis Klasifikasi Tinggkat Kesehatan Lembaga Perkreditan Desa (Lpd) Menggunakan Metode K-Means Clustering, J. Teknol. Inf. dan Komput., Vol. 5, No. 1, Pp. 83-90, Doi: 10.36002/Jutik.V5i1.641.

[9] R. Efendi, F. F. Coastera, And F. . Tanjung. 2019, Pengelompokan dan Pemetaan Derajat Kesehatan Kota Bengkulu Dengan Metode K-Means Clustering, J. Rekursif, Vol. 7, No. 1, Pp. 91-97, [Online]. Available: Https://Ejournal.Unib.Ac.Id/Index.Php/Rekursif/Article/View/7097/4003.

[10] C. S. Journal, R. Ordila, R. Wahyuni, Y. Irawan, And M. Y. Sari, 2020, Penerapan Data Mining Untuk Pengelompokan Data Rekam Medis Pasien Berdasarkan Jenis Penyakit Dengan Algoritma Clustering (Studi Kasus: Poli Klinik PT . Inecda), Vol. 9, No. 2, Pp. 148-153.

[11] F. Wulandari And P. A. Jusia, 2020, Klasifikasi Data Mining Untuk Mendiagnosa Penyakit Ispa Menggunakan Metode Nä̈ve Bayes pada Puskesmas Jambi Selatan, Vol. 2, No. 3, Pp. 214-227.

[12] J. Wandana, S. Defit, And S. Sumijan. 2020, Klasterisasi Data Rekam Medis Pasien Pengguna Layanan BPJS Kesehatan Menggunakan Metode K-Means, J. Inf. dan Teknol., Vol. 2, Pp. 4-9, Doi: 10.37034/Jidt.V2i4.73.

[13] S. A. Rahmah. 2020, Klasterisasi Pola Penjualan Pestisida Menggunakan Metode KMeans Clustering (Studi Kasus Di Toko Juanda Tani Kecamatan Hutabayu Raja), Vol. 1, No. 1, Pp. 1-5.

[14] Y. Darnita, R. Toyib, And Y. Kurniawan. 2020, Penerapan Metode K-Means Clustering pada Aplikasi Android pada Tanaman, Vol. VII, No. September, pp. 105-114. 